Pak. J. Agri. Sci., Vol. 55(2), 423-426; 2018

ISSN (Print) 0552-9034, ISSN (Online) 2076-0906

DOI: 10.21162/PAKJAS/18.3544

http://www.pakjas.com.pk

\title{
EFFECT OF BREEDING Bos indicus WITH Bos taurus ON AGE AT FIRST CALVING IN PAKISTANI ADMINISTRATIVE KASHMIR
}

\author{
Muhammad Ijaz Khan ${ }^{1, *}$, Samina Jalali ${ }^{2}$, Beenish Shahid ${ }^{3}$ and Sajjad Aslam Shami ${ }^{4}$ \\ ${ }^{1}$ Livestock Development Research Centre (LDRC), Muzaffarabad, Azad Jammu and Kashmir, Pakistan; ${ }^{2}$ \\ Department of Animal Science, Faculty of Biological Science, Quaid-i-Azam University, Islamabad, Pakistan; \\ ${ }^{3}$ Department of Zoology, University of Azad Jammu and Kashmir, Muzaffarabad, Pakistan; ${ }^{4}$ Department of Animal \\ Science, Faculty of Biological Science, Quaid-i-Azam University, Islamabad, Pakistan \\ *Corresponding author's e-mail: ijaznrsp@gmail.com
}

\begin{abstract}
The objective of this study was to reduce the age at first calving of Bos indicus by crossing with Bos taurus in Pakistani administrative areas of Kashmir. A total of 48 indigenous cows, 32 Indigenous x Jersey (F1), 19 Indigenous x Jersey (F2) and 18 Indigenous $x$ Jersey $\times$ Friesian cows were used to compare their age at first calving. The lowest mean age at first calving was observed in $F_{1}$ and $F_{2}$ hybrid cows where it was $951.2 \pm 37.35$ and $1086 \pm 37.89$ days respectively, followed by $F_{1} \times$ Friesian (1086 \pm 37.89$)$ while the highest mean age at first calving was observed in nondescript indigenous (Bos taurus) cows (1861 \pm 42.45 days). Analysis of variance showed that the mean age at first calving decreased highly significantly in $\mathrm{F}_{1}(\mathrm{P}<0.05) ; \mathrm{F}_{2}$ $(P<0.05)$ and $F_{1} \times$ Friesian $(P<0.05)$ cows compared to that of nondescript indigenous cows. Mean age at first calving of $F_{1}$ hybrid cows did not differ significantly $(P>0.05)$ compared to $F_{2}$ and $F_{1} \times$ Friesian cows. Similarly, the mean AFC of $F_{2}$ and $F_{1} \times$ Friesian did not differ significantly $(P>0.05)$ from each other. No sire effect was found on age at first calving within $F_{2}$ and cross bred (P > 0.05). In future crossing of Bos indicus with Bos taurus should be continue for the up gradation of indigenous cows and maximum of 50\% exotic genes should allow to be incorporated in the female stock.
\end{abstract}

Keywords: Bos indicus, crossbreeding, grading up, indigenous cows, sub-tropical.

\section{INTRODUCTION}

In Azad Jammu and Kashmir (AJK) the majority of the rural population depends on forestry, livestock and agriculture to eke-out its subsistence. Low agriculture productivity has very adversely affected the traditional lifestyle and average per capita income of the rural household. The productivity of dairy cattle in AJK is very low, this may be attributed to poor genetic makeup of indigenous cattle (Khan et al., 2014). The indigenous cattle of AJK are small sized with live weight ranges from 175 to $225 \mathrm{~kg}$ (Tanner, 1978). Reproductive performance of breeding cow is one of the most important factor that is a prerequisite for sustainable dairy production system and influencing the productivity (Alemayehu and Moges, 2014). Age at first calving (AFC) is one of the most important reproductive trait. The AFC of indigenous cattle of AJK is very high compared with European dairy breed. AFC is one of the important factors that contributes in economic return and a reduction in AFC will minimize the raising cost, shorten the generation interval, and subsequently increase the number of lactation per animal (Zewdu et al., 2015). the Cow's productive life starts with first calving. An early AFC decreases the generation interval. Early age at first calving results in more calves and milk during the life time of a cow. Therefore, AFC is one of the most important economic traits of dairy cattle. Age at first calving has an important bearing on early economic return on total lifelong production (Mourad, 1997). As generally indicative to a better management index at farm level average age of first calving should be optimally around 2 years (Wiltbank, 1970). To improve the productivity of indigenous cattle a crossbreeding program was started in 1990 for the very first time in AJK. The present research was conducted to improve the productivity by increasing the milk production and reducing the AFC of of indigenous Bos indicus cattle by crossing with Bos taurus such as Jersey and Friesian and to access the adaptability of crossbred cattle in sub-tropical highland type environment of AJK.

\section{MATERIALS AND METHODS}

Animals and farm: Livestock Development Research Centre (LDRC) is located at the bank of river Jhelum 6 kilometres away from the main city of Muzaffarabad which is the capital of AJK. This farm was established 1940 by the Government of Azad Jammu and Kashmir by purchasing of indigenous cattle. The cows have been kept in farms the roof constructed from asbestos sheet and iron bar, the floor is of concrete.

Breeding scheme: In 1990 a crossbreeding program was started. In first type of crosses F1 (Indigenous $\times$ Jersey) offspring were produced. F1 offspring's calving occurred from July, 1991 to April, 1998. In second type of cross F1 
offspring were crossed among them self, as a result of which F1 $\times$ F1 (F2) offspring were produced during the period of May, 1994 to April, 1999. In third type of cross the three breed crossbred cows $(25 \%$ indigenous $+25 \%$ Jersey +50 $\%$ Friesian) were developed by crossing F1 female with pure Friesian bull during May 1994 to April 1999.

Feeding regime: Cows were fed on forage (elephant grass and maize, green berseem and oats) roughages comprised of wheat straw and stoves of maize. The concentrate mixture (composed of wheat bran, rape seed cake and cotton seed cake and molasses). Lumps of common salts (sodium chloride) were placed in manger and cows were free to lick.

Data collection: It is a retrospective study, carried out over a period from 1990-2010. The data regarding productive and reproductive records of 84 cows out of which 37 were indigenous, 25 were $F_{1}$ (Indigenous $\times$ Jersey), 8 were $F_{1} \times F_{1}$ $\left(\mathrm{F}_{2}\right)$ and 14 were $\mathrm{F}_{1} \times$ Friesian cows.

Age at first calving: Age at first calving of cows was calculated by the interval between the date of birth and the date of calving of a heifer following pregnancy of full term.

Statistical analysis: The difference in the mean AFC among the four breed groups were worked out through analysis of variance. Graph Pad Prism 5 package was used for statistical analysis. Difference was significant when $\mathrm{P}<0.05$.

\section{RESULTS AND DISCUSSION}

Mean age at first calving of indigenous and crossbred dairy cows is given in Table 1. Mean age at first calving was highest in nondescript indigenous cows $(1861 \pm 42.45$ days $)$ followed by $F_{1} \times$ Friesian $(1086 \pm 37.89)$ while lowest was found in $F_{1}$ and $F_{2}$ hybrid cows where it was $951.2 \pm 37.35$ and 1086 \pm 37.89 days respectively. Analysis of variance showed that the mean age at first calving decreased highly significantly in $\mathrm{F}_{1}(\mathrm{P}<0.05) ; \mathrm{F}_{2}(\mathrm{P}<0.05)$ and $\mathrm{F}_{1} \times$ Friesian $(\mathrm{P}<0.05)$ cows compared to that of nondescript indigenous cows. Mean age at first calving of $\mathrm{F}_{1}$ hybrid cows did not differ significantly $(\mathrm{P}>0.05)$ compared to $\mathrm{F}_{2}$ and $\mathrm{F}_{1} \times$ Friesian cows. Similarly, the mean $\mathrm{AFC}$ of $\mathrm{F}_{2}$ and $\mathrm{F}_{1} \times$ Friesian did not differ significantly $(\mathrm{P}>0.05)$ from each other.

No sire effect was found on age at first calving within $F_{2}$ crossbred. Analysis of variance indicated that there were no variations of age at first calving among daughters of sire 1 sire 2 and sire 3 and the differences did not differ significantly ( $P$ $<0.05)$. Similar to $F_{1}$ crossbred cows age at first calving was not affected by sire within $\mathrm{F}_{1} \times$ Friesian crossbred cows $\mathrm{t}_{(15)}$ $=0.3025 ; \mathrm{P}>0.05)$.

Present study revealed that the mean AFC of indigenous cows (1861 \pm 42.45 days) was higher than the mean AFC of local cows from some Asian countries such as in Deshi cattle (47 \pm 7 months) of India (Moulick et al., 1972); Deshi cattle (1365 \pm 6.20 ) of West Bengal (Sarkar et al., 2007); Gray cattle (1191 \pm 19.7 days) of North Bengal (Al-Amin et al., 2007) and indigenous cow of (40.48 \pm 4.54 months) Bangladesh (Rokonuzzaman et al., 2009). Mean AFC of indigenous cow in this study was also higher than the mean AFC of cows from African countries such as local cattle of Northern Ethiopia has an AFC of $3.41 \pm 0.70$ years (Weldeslasse et al., 2012).

The AFC of Jersey cows in different countries was found to be $888.53 \pm 15.97$ days in Pakistan (Lateef et al., 2008); 946 days in Russia (Denisava, 1981); $956.24 \pm 35.82$ days in India (Matoch and Tomar, 1983) and 945.93 days in Nigeria (Adeneye, 1985). As a result of crossbreeding of indigenous cows with Jersey in this study the mean AFC in indigenous cows decreased significantly in crossbred cows. The lowest mean AFC was observed in $\mathrm{F}_{1}$ crossbred cows $(951.2 \pm 37.35$ days) and it was comparable to that of Jersey cows (926.48 \pm 10.29 days) studied by (Sattar et al., 2004); lower than the mean AFC of imported Jersey cows (1010.73 \pm 21.84 days $)$ (Suhail et al., 2010) but higher than the mean AFC of farm born Jersey cows $(888.53 \pm 15.97)$ observed by Lateef et al. (2008) under subtropical conditions of Pakistan. Mean AFC of $F_{1}$ crossbred cows in present study was lower than the findings of (Zaman et al., 1983) for $\mathrm{F}_{1}$ (Jersey $\times$ Sahiwal) cows $(793.7 \pm 10.76$ days $)$ at Livestock Experiment Station Bahadurnagar, Pakistan and $\mathrm{F}_{1}$ (Jersey $\times$ Dehsi) cows $(1002.3$

Table 1. Comparative AFC of indigenous and crossbred dairy cows developed at Livestock Development Research Centre (LDRC) Muzaffarabad, Azad Kashmir.

\begin{tabular}{|c|c|c|c|}
\hline Breed Groups & & Age at First Calving & Range \\
\hline Indigenous & & $1861 \pm 42.45(48)$ & $1080-2543$ \\
\hline Indigenous $\times$ Jersey $\left(F_{1}\right)$ & & $951.2 \pm 37.35^{\mathrm{a}^{* * *}}(32)$ & $712-1249$ \\
\hline \multirow[t]{4}{*}{$\mathrm{F}_{1} \times \mathrm{F}_{1}\left(\mathrm{~F}_{2}\right)$} & Sire 1 & $1024 \pm 69.38(9)$ & $736-1383$ \\
\hline & Sire 2 & $1130 \pm 26.58(8)$ & $1073-1277$ \\
\hline & Sire 3 & $1192 \pm 126(2)$ & $1066-1318$ \\
\hline & Overall & $1086 \pm 37.89^{\mathrm{a}^{* * *}}(19)$ & $736-1383$ \\
\hline \multirow[t]{3}{*}{$\mathrm{F}_{1} \times$ Friesian } & Sire 1 & $965.2 \pm 38.39(11)$ & $789-1137$ \\
\hline & Sire 2 & $946.2 \pm 47.61(6)$ & $798-1108$ \\
\hline & Overall & $952.1 \pm 28.23^{\mathrm{a}^{* * * *}}(18)$ & $789-1137$ \\
\hline
\end{tabular}


\pm 49.4 days) in Bangladesh Agriculture University (Nahar et al., 1992).

As a result of selfing of $F_{1}$ offspring mean AFC increased in $\mathrm{F}_{2}$. This increase may be due to segregation of genetics factors. However, when $F_{1}$ crossbred cows were crossed with Friesian bull then in $\mathrm{F}_{1} \times$ Friesian cows the mean AFC became almost equal to that of $F_{1}$ crossbred cows.

Mean AFC of Holstein Friesian cows was $944.08 \pm 12.71$ days in Pakistan (Younas et al., 2008); $927.81 \pm 115.6$ days in Chile, $924.64 \pm 15.21$ days in Ghana (Perez et al., 1985) and 888.14 in USA (Gyawn et al., 1988). Mean AFC in $\mathrm{F}_{1} \times$ Friesian cows in present study was comparable as indicated in farm born Holstein Friesian cows in Punjab (952.90 15.14 days) (Lateef et al., 2008); Holstein Friesian cows (987.87 \pm 9.81 days) in Pakistan (Sattar et al., 2004). Rokonuzzaman et al. (2009) recorded a mean AFC in Indigenous $\times$ Friesian cow (34.12 \pm 3.78 months) in Bangladesh is also comparable to the findings of $\mathrm{AFC}$ in $\mathrm{F}_{1} \times$ Friesian cows in this study.

Mean AFC in $\mathrm{F}_{1}$ (Holstein Friesian $\times$ Dehsi) cows (1201.4 \pm 29.6 days) at Bangladesh Agriculture University (Nahar et al., 1992) was higher than mean AFC in $F_{1} \times$ Friesian cows in present study but it was lower in Friesian $\times$ Non-Descript cows (888.0 \pm 21.47 days) in Pakistan (Zaman et al., 1983).

Conclusion: The present study suggests that age at first calving can be reduced in indigenous cattle of Azad Jammu and Kashmir by crossing with exotic breed of Jersey and Friesian.

Acknowledgment: The authors would like to express their gratitude to the Livestock Development Research Centre (LDRC) and all of its staff members whose hard work and cooperation made this study possible. We greatly acknowledge the Department of Animal Husbandry Govt. of the AK\&K Muzaffarabad for the provision of data. Special thanks to Dr. Moshin Ali Mirza Senior Research Officer LDRC for their cooperation.

\section{REFRENCES}

Adeneye, J.A. 1985. Calf production, calving interval and herd life of imported Jersey cattle in Ibadan, Western Nigeria. Trop. Veterinarian 3:437-441.

Al-Amin, M., A. Nahar, A.K.F.H. Bhuiyan and M.O. Faruque. 2007. On-farm characterization and present status of North Bengal Grey (NBG) cattle in Bangladesh. Anim. Gen. Resour. 40:55-64.

Denisova, T.A. 1981. Reproductive performance of Russian Black Pied $\times$ Jersey $\times$ Holstein Friesian crossbreds. Anim. Breed. Abst. 52:2448.

Gyawn, P., K. Asare and P.K. Karikari. 1988. The performance of imported Holstein Friesian cattle and their progeny in the humid tropics. Bull. Anim. Heal. Prod. 36:362-66.
Lateef, M., K.Z. Gondal, M. Younas, M. Mustafa and M.K. Bashir. 2008. Reproductive performance of Holstein Friesian and Jersey cattle in Punjab, Pakistan. Pak. J. Agri. Sci. 45:245-249.

Matoch, S. and N.S. Tomar. 1983. Performance of imported Jersey heifers in India. Ind. Vet. Res. J. 6:63-66.

Nahar, T.N., M. Islam and M.A. Hasnath. 1992. A comparative study of $F_{1}$ crossbred cows under rural conditions. Asian. J. Anim. Sci. 5:435-38.

Perez, C.C., L.G. Buzzettil, P.N. Barria and M.F. Gonzalez. 1985. Milk yield characters in Holstein- Friesian cows in the metropolitan region of Chile. 1. Phenotypic characters and factors affecting variations. Cin. Invest. Agrar. 12:121-28.

Rokonuzzaman, M., M.R. Hassan, S. Islam and S. Sultana. 2009. Productive and reproductive performance of crossbred and indigenous dairy cows under small-holder farming system. J. Bangladesh Agri. Univ. 7:69-72.

Sarder, M.J.U. 2001. Reproductive and productive performances of indigenous cows. The Bangla. Vet. 18:123-9.

Sarkar, A., K.C. Dhara, N. Ray, A. Goswami and S.K. Ghosh. 2007. Physical characteristics, productive and reproductive performances of comparatively high yielding Deshi Cattle of West Bengal, India. Livest. Res. $\begin{array}{llll}\text { Rural. } & \text { Dev. } & 19 & \text { (9). }\end{array}$ http://www.lrrd.org/lrrd19/9/sark19122.htm

Sattar, A., R.H. Mirza and I. Ahmad. 2004. Reproductive efficiency of Jersey cows under subtropical conditions of the Punjab. Pak. Vet. J. 24:129-33.

Suhail, S.M., I. Ahmed, A. Hafeez, S. Ahmed, D. Jan, S. Khan and Altaf-Ur-Rehman. 2010. Genetic study of some reproductive traits of Jersey cattle under subtropical conditions. Sarhad. J. Agric. 26:87-91.

Tanner, S.C. 1978. The livestock industry of Azad Jammu and Kashmir. UNDP/FAO/Coordinated National Programme for Livestock and Dairy Development, Pakistan, PAK/74/018. pp 144.

Tonhati, H., F.B. Vascocellos and L.G. Alburquerque. 2000. Genetic aspects of productive and reproductive traits in a Murraha buffalo herd in Sao Paulo, Brazil. J. Anim. Breed. Genet. 117:331-9.

Weldeslasse, G.T., Z.M. Zeleke and S.K. Gangwar. 2012. Reproductive and productive performance of dairy cattle in central zone of Tigray, Northern Ethiopia. Int. J. Adv. Biol. Res. 2:58-63.

Wiltbank, J.B. 1970. Research needs in beef cattle reproduction. J. Anim. Sci. 3:755-62.

Younas, M., M. Bilal, M.E. Babar, M. Yaqoob and A. lqbal. 2008. Reproductive profile of Holsteins kept in Baluchistan province of Pakistan-ii. Pak. J. Agri. Sci. 45:280-87. 
Zaman, M., I. Haider, M.A. Farooq and S.K. Shah. 1983. Production performance and adaptability of crossbred cows. Pak. J. Agric. Res. 4:180-89.

Khan M.I., S. Jalali, B. Shahid, S.A. Shami. 2014. Breeding efficiency of Indigenous $\times$ Jersey, Indigenous $\times$ Jersey $\times$ Friesian crossbred cows at Livestock Development Research Centre, Muzaffarabad, Azad Jammu and Kashmir. Proc. Pak. Acad. Sci. 51:289-294.
Zewdu, W., B.M. Thombre, D.V. Bainwad. 2015. Studies on some non-genetic factors effecting reproductive performance of Holstein Friesian $\times$ Deoni crossbred cows. Afr. J. Agric. Res. 10:1508-1516.

Alemayehu, S. and N. Moges. 2014. Study on reproductive performance of indigenous dairy cows at small holder farm conditions in and around Maksegnit Town. Glob.Vet.13:450-454. 